\title{
2 Samuel 21-24: A theological reflection on Israel's kingship
}

\author{
Grace Ko (Tyndale University COLlege ANd Seminary)
}

\begin{abstract}
The chiastic arrangement of 2 Sam 21-24 signifies that it is not just a collection of miscellaneous material supplementing the Samuel corpus. Rather it is intentionally arranged to function as a theological reflection on Israel's kingship. This paper shows that the three pairs of literary elements, namely, the two narratives (2 Sam 21:1-14; 24:1-25); the two lists of warriors (21:15-22; 23:8-39); and the two poems $(22: 1-51 ; 23: 1-7)$, demonstrate divine responses to Israel's request for a king. Despite his displeasure of their request, God grants Israel their wish and installs kings for them. The two narratives show the failure of human kingship that brings calamity to the people. The warrior lists are the manifestations of God's providence in giving them fighters. The two poems reveal divine election of David as his messiah and that Israel's ideal kingship should be under the governance and supremacy of their divine King, Yahweh.
\end{abstract}

\section{A INTRODUCTION}

Karl Budde was the first scholar to observe that there are six elements in 2 Sam 21-24: two narratives $(21: 1-14 ; 24: 1-25)$, two lists of warriors $(21: 15-22 ; 23: 8$ $39)$ and two poems $(22: 1-51 ; 23: 1-7)$ arranged in a chiastic structure. ${ }^{1}$ Many scholars have since come to adopt this pattern, but few engage in finding out the function and purpose of this section. ${ }^{2}$ This closing section of the books of Samuel is usually treated as an appendix, supplementing the whole Samuel corpus with miscellaneous material and events that are not previously recorded in the books of Samuel. But the highly artistic chiasmus shows that this section is more than

* Submitted: 17/08/2017; peer-reviewed: 22/09/2017; accepted: 06/12/2017. Grace Ko, "2 Samuel 21-24: A Theological Reflection on Israel's Kingship,” OTE 31 no. 1 (2018): 114-134. DOI: https://doi.org/10.17159/2312-3621/2018/v31n1a7

1 For Budde's view and his speculation of the original text units of 2 Sam 21-24, see Antony F. Campbell, "2 Samuel 21-24: The Enigma Factor," in For and against David: Story and history in the Books of Samuel, ed. A. Graeme Auld and Erik Eynikel (Leuven: Peeters, 2010), 348, footnote 4.

2 David G. Firth, review of II Samuel 21-24: Context, structure, and meaning in the Samuel conclusion, by Herbert H. Klement, OTE 15 (2002): 831-33, shows that Klement's book is an effort to investigate the function of these chapters as a conclusion to the whole Samuel corpus. 
just an appendix or an "aside." ${ }^{33}$ Rather it is intentionally arranged to highlight its purpose as the conclusion of the books of Samuel.

Scholars differ in their opinions as to how this section relates to the royal theology. Walter Brueggemann, who follows the lead of R. A. Carlson, ${ }^{4}$ views it as a critique of royal ideology. ${ }^{5}$ Antony F. Campbell suggests that this is the "third wave" of Davidic tradition, which portrays David in a more negative light. ${ }^{6}$ Others, though recognizing the weaknesses and shortcomings of David, view it as a positive evaluation on David's kingship, and an affirmation of Davidic dynasty. Brevard Childs concluded that these final four chapters "offer a highly reflective, theological interpretation of David's whole career adumbrating the messianic hope, which provides a clear hermeneutical guide for its use as sacred scripture."

In this paper, I intend to do a literary analysis of the text, harking back to earlier incidents in the books of Samuel when necessary. The purpose is to show that the final four chapters of 2 Samuel serve as a theological reflection on Israel's request for king and the divine provisions to shape and guide Israel as it evolves from a tribal league to a monarchy. To achieve this goal, I will first examine the six elements in these four chapters and point out their functions in the summary section. I will study how each element answers some of the issues raised in the books of Samuel, and how these elements contribute to the theology of the books. Then I will investigate Yahweh's dealings with the first two kings of Israel to understand the reasons for Saul's rejection and David's election and to clear any accusation of Yahweh playing favouritism.

\section{B STRUCTURE OF 2 SAMUEL 21-24}

Most scholars see the structure of 2 Sam 21-24 as arranged in a chiasmus: ${ }^{8}$

3 Robert D. Bergen, 1, 2 Samuel, NAC (Nashville: Broadman \& Holman, 1996), 441.

4 Rolf A. Carlson, David, the Chosen King: A Traditio-Historical Approach to the Second Book of Samuel (Uppsala: Almqvist \& Wiksell, 1964), 194-259.

5 Brueggemann proposes the function of this section as "to deconstruct and to combat the well-established royal theology." (See his article, Walter Brueggemann "2 Samuel 21-24: An Appendix of Deconstruction?" CBQ 50 (1988): 385.)

6 Campbell, "2 Samuel 21-24," 347. For a critique of his view, see Auld's response, A. Graeme Auld, "A Factored Response to An Enigma," in For and Against David: Story and History in the Books of Samuel, ed. A. Graeme Auld and Erik Eynikel (Leuven: Peeters, 2010), 359-66.

7 Brevard S. Childs, Introduction to the Old Testament as Scripture (Philadelphia: Fortress, 1979), 275.

8 Klement demonstrates that this chiasmus is in line with the macrostructure of the whole book of Samuel. He opines that the macrostructure is not based on "linearchronological principles but according to patterns of parallelism and chiasmus." See his 


\section{Ko, "2 Samuel 21-24,” OTE 31/1 (2018): 114-134}

A Famine: Divine judgment on Saul's sin (21:1-14)

B List of David's warriors (21:15-22)

C David's Song of Thanksgiving (22:1-51)

C' David's last words (23:1-7)

B' List of David's warriors (23:8-39)

A' Plague: Divine punishment on David's sin (24:1-25)

The two narratives $(21: 1-14 ; 24: 1-25)$ which frame this section feature the divine judgments of Israel because of the sins of her first two kings, Saul and David. ${ }^{9}$ These accounts partially fulfil Samuel's warning to the Israelites that if they are bent on sinning, both they and their king will incur judgment from the Lord (1 Sam 12:15, 25). The second tiers of the chiasmus are the lists of David's warriors (21:15-22; 23:8-39), which not only democratize the honour that usually is attributed to the kings, but also show God's providence for these valiant warriors to help David to build his kingdom. ${ }^{10}$ The core of the chiasmus consists of two Davidic poems $(22: 1-51 ; 23: 1-7)$ which focus on the sovereignty and dependability of Yahweh as well as Israelite royal ideology according to Deut 17:14-20. We shall now discuss each pair of the elements in detail.

\section{FAMINE AND PLAGUE}

\section{Samuel 21:1-14}

This narrative begins with a famine during David's reign for an extensive period of three years and upon David's inquiry to the Lord, an oracle was given for the reason of the famine. It was the divine punishment of Saul's bloodguilt against the Gibeonites. The Gibeonites had deceived the Israelites to make a covenant with them in Joshua's day (Josh 9:1-27) and Joshua subsequently ordered them to do the hard work but spared their lives. Yet "Saul in his zeal for Israel and Judah had tried to annihilate them"11 (v. 2b). When David sought reconciliation with the Gibeonites, they requested to have seven of Saul's descendants to be killed to avenge the blood guilt (vv. 4-6). David quickly complied and handed over two of Saul's sons by his concubine Rizpah, and five of Saul's grandsons by his daughter Merab. ${ }^{12}$ But Jonathan's son Mephibosheth was spared because

article, Herbert H. Klement, "Structure, Context and Meaning in the Samuel Conclusion (2 Sam. 21-24)," TynBul 47 (1996): 368-69.

9 These two narratives share a similar structure. See Gerald Sheppard, Wisdom as a Hermeneutical Construct: A Study in the Sapientializing of the Old Testament (Berlin: de Gruyter, 1980), 148 fn. 62.

10 Robert B. Chisholm, 1 \& 2 Samuel, TTCS (Grand Rapids: Baker, 2013), 293-4.

11 The same verb נכה is used in both Josh 9:18 and 2 Sam 21:2. While in Joshua the Israelite leaders refused to attack the Gibeonites because of their oath, Saul refused to honor the treaty that they made before the Lord and sought to annihilate them.

12 MT text has "Michal," which is certainly wrong, for Merab was the wife of Adriel (1 Sam 18:19), and Michal was barren (2 Sam 6:23). Cephas Tushima's argument that 
of David's covenant with Jonathan. The famine incident then closes with the proper burial of the bones of Saul and Jonathan, along with his doomed descendants, after Rizpah's courageous and poignant deed of guarding the corpses of Saul's descendants. Then "after that God answered prayer on behalf of the land" (21:14).

Brueggemann suspects that the whole incident is David's ruse to find an excuse to kill off the Saulides. ${ }^{13}$ But by inserting lengthy background information in 21:2, the author painstakingly explains that David was innocent for their deaths. Even though David was the one who handed them over to the Gibeonites, he was doing it as a righteous king to ensure that justice was carried out and that the well-being of his subjects maintained. Sheppard also saw this "recollection provides an apologetic for David's innocence in the matter and, more importantly, acknowledges his subsequent ability to seek God and take the right course of action." 14

I find Brueggemann's argument untenable at several points. ${ }^{15}$ First of all, he claims that "the Saul-element in the Gibeon crisis is missing" because there is no mention of such a crime in the books of Samuel. However, the earlier text in 2 Sam 4:2-3 may have provided a hint of this incident by mentioning the fleeing of the residents of Beeroth, which was originally a Gibeonite city but later was considered to belong to Benjamin. ${ }^{16}$ The reason for the Beerothites to flee their city might be due to Saul's attempt to annihilate them, and subsequently Beeroth was overtaken by the Benjamites. ${ }^{17}$

Michal was the mother of the five slain Saulides is forced and needs to change the identity of the husband, also, more importantly, his view runs counter to the plain meaning of the text. See Cephas Tushima, The Fate of Saul's Progeny in the Reign of David (Cambridge, UK: James Clarke \& Co, 2011), 216-20.

13 Brueggemann, "2 Samuel 21-24," 385-6.

14 Sheppard, Wisdom as a Hermeneutical Construct, 147.

15 Even Brueggemann himself admits that his suspicious reading "is not necessary exegetically," see Brueggemann, "2 Samuel 21-24," 386.

16 See Cartledge's discussion "Why Is This Strange?" in his commentary, Tony W. Cartledge, $1 \& 2$ Samuel, SHBC (Macon: Smyth \& Helwys, 2001), 402. Originally the four Gibeonite cities were Gibeon, Chepirah, Beeroth, and Kiriath-Jearim (Josh 9:17). Even though these cities were later allotted to the tribe of Benjamin (Josh 18:25-28), Israelites' treaty with them should guarantee their right of existence.

17 Most scholars assume that their flight was to escape Saul, see P. Kyle McCarter Jr., II Samuel: A New Translation with Introduction and Commentary, AB (Garden City: Doubleday, 1984), 127; Tushima, Fate of Saul's Progeny, 149. Some may want to argue that the fleeing of the Beerothites was a result of the assassination of Isbosheth by the Rimmon brothers, but the background information on 2 Sam 4:2-3 indicates that the fleeing happened before the murder. 
Secondly, Brueggemann doubts the veracity of the reason for the famine and Saul's involvement in it since both accounts are from a "private oracle."18 While the text is silent on whether the oracle is of a private or public nature, it was David's common practice to seek oracles from Yahweh (1 Sam 23:2, 9-11; 30:8; 2 Sam 2:1; 5:19, 23). ${ }^{19}$ Thus it is not surprising that David would seek (בקש) the favour of the Lord to end the famine, since famine is usually seen as the judgment of God. Even if the seeking of the oracle was private, the meeting with the Gibeonites had to be public. It is highly unlikely that David could coerce them to engage in such a plot against Saulides if Saul had never harmed them. ${ }^{20}$ Moreover, as Philip E. Satterthwaite observes, "it is hard to believe that a narrator who lays so much stress on God's role throughout the narrative means to portray David's action as based on a transparent fiction." 21

Some may argue that David seemed too eager to hand over the remaining of the Saulide clans to the Gibeonites (21:6). But David's words to the Gibeonites in 21:4e, "What you are saying I would do for you," bound himself to their demands. ${ }^{22}$ The narrator is also quick to point out that David spared Mephiboshet because of his covenant with Jonathan (21:7), which shows that David's choice

18 Brueggemann, "2 Samuel 21-24," 386. Fokkelman criticizes Brueggemann for providing a confusing exegesis and ideology. See his book, Jan P. Fokkelman, Throne and City: II Samuel 2-8 and 21-24, vol. 3 of Narrative Art and Poetry in the Books of Samuel: A Full Interpretation Based on Stylistic and Structural Analysis (Assen: Van Gorcum, 1990), 290 fn. 17.

19 Tushima, Fate of Saul's Progeny, 211-12, tries to bolster his suspicious reading by arguing from silence that there is no mention of priestly official or prophetic figure. But out of the six other times that David inquired of Yahweh (1 Sam 23:2, 9-11;30:8; 2 Sam $2: 1 ; 5: 19 ; 5: 23)$, only twice were a priest with ephod specifically mentioned (1 Sam 23:9-11; 30:8). He also questions the use of the word (seek) instead of the more commonly used verb דרש (inquire), but the verb that is used in 2 Sam 2:1; 5:19; 5:23 is שרש not, showing that the author does use different words. In this passage, ויבקש דוד את־ David was imploring the Lord (literally, "seeking the face of the Lord" after three years of famine, so the use of this verb בקני יהוה is most appropriate since it carries the meaning of seeking mercy and repenting (cf. same verb is used in 2 Sam 12:16).

20 The Gibeonites stated right at the beginning that the matter between them and Saul and his house could not be resolved by monetary recompense, which prompted David to promise to do whatever they asked (2 Sam 21:4). Tushima's opinion that the Gibeonites was ready to let go but that David gave them a "blank check" to coerce them to request for the seven Saulides contradicts the text, for the solemn request was made by the Gibeonites themselves. See Tushima, Fate of Saul's Progeny, 214-15.

21 Philip E. Satterthwaite, "David in the Book of Samuel: A Messianic Hope?" in The Lord's Anointed: Interpretation of Old Testament Messianic Texts, ed. Philip E. Satterthwaite, Richard S. Hess, and Gordon J. Wenham (Grand Rapids: Baker, 1995), 62.

22 Fokkelman, Throne and City, 278. 
was not out of his own "personal arbitrariness." ${ }^{23}$ By sparing Mephiboshet, David kept his promise to both Jonathan (1 Sam 18:3; 20:14-17; 23:16-18) and Saul (1 Sam 24:21).

Thirdly, Sellar argues that from Saul's behaviour in 1 Sam 13-15, he had a propensity to gain favour from the populace. ${ }^{24}$ However, her conclusion that Saul was a people's king and not the tyrannical type is flawed. The three incidents she cites, namely Saul's failure to wait for Samuel; Saul's unwise rash oath which nearly cost Jonathan's life; and Saul's failure to obey Yahweh's ban on the Amalekites in 1 Sam 13-15, demonstrate that Saul was not an effective leader. These incidents also show that Saul's faith wavered when facing tough situation and his incapability to make right decisions. Moreover, Saul incriminated himself as a tyrannical monarch when he accused his fellow Benjamites of siding with David by claiming that it was he who gave them "fields and vineyards," and made them "commanders of thousands and commanders of hundreds" (1 Sam 22:7), his words reminiscent of Samuel's earlier warning of a tyrannical monarch $(8: 12,14) .{ }^{25}$ His subsequent action of massacring the priestly city of Nob further proves that he was a vicious tyrant who would resort to brutality against his own citizens. Due to Saul's preference for popular support it is not improbable that he would seek to please the people and gain their favour by exterminating the Gibeonites.

Hence the purpose of this narrative, rather than to deconstruct, is to defend David's action of handing over Saul's descendants to the Gibeonites who then put them to death to avenge the crime that Saul had committed against them. ${ }^{26}$

23 Fokkelman, Throne and City, 281-2.

24 Dawn Maria Sellars, "An Obedient Servant? The Reign of King Saul (1 Samuel 1315) Reassessed," JSOT 35 (2011): 317-38. Exum and Whedbee also comment that the incidents of 1 Sam $13 \& 15$ allow us to see "Saul's personality and the motivation behind his decisions, particularly his desire to win the favor of the people." See their article, J. Cheryl Exum and J. William Whedbee "Isaac, Samson, and Saul: Reflections on the Comic and Tragic Visions," Semeia 32 (1984): 28.

25 Some may argue that Saul was not claiming these things at his disposal but rather was accusing the Benjamites of deserting him for David who tried to lure them with false promises of fields, etc. But it was a common practice in ANE that the king appointed his kinsmen and family members to top government offices. Saul was reminding his officials (Benjamites) that it was he who had given them prosperity and that they had much to lose if they helped David.

26 This may sound cruel and unfair to our modern ears, but in ancient Israel, corporate guilt is possible, especially when it is a violation of religious matters, e.g., the action of Achan that caused Israel to lose the battle and the lives of thirty-six warriors and the subsequent stoning of Achan and his family in Josh 7. Since the making of covenant involves the witnesses of deities, it is not just a political issue but a religious one as well. Hence the demand of the Gibeonites is not regarded as vindictive but as a means of purging the land from sin. 
The reason is to put any suspicion of David's wrongdoing to rest. ${ }^{27}$ David is seen here as a responsible king who helps to right the wrong and facilitates the end of the famine. ${ }^{28}$ This narrative also shows that Yahweh is a righteous and faithful God and he will not allow any injustice and treachery to go unpunished.

\section{$2 \quad 2$ Samuel 24:1-25}

While the above famine narrative may have shown Yahweh in a positive light, many readers may find this closing narrative puzzling and troubling. In this episode, Yahweh appeared to be unreasonable, if not capricious, for he incited David to take a census because he was angry with the Israelites. He then turned around to punish David for his "wrong doing." And to make things even more bizarre, God offered David three choices of punishment: three years of famine, ${ }^{29}$ three months being pursued by the enemies, or three days of plague in his country. David chose the last option, trusting in God's mercy (רחמים). ${ }^{30}$ After the death of seventy thousand in the country, God finally ordered the destroying angel to halt his hand as he was about to strike Jerusalem. David then bought and built an altar on the threshing floor of Araunah the Jebusite and offered the sacrifices to Yahweh and the plague stopped. That site, according to 1 Chr 21:28-22:1, became the site for the future temple built by Solomon.

Several issues are raised by this passage: How could God incite his chosen king to do a wrong thing to punish his people? What sin did David commit by ordering a census? And what did Israel do to provoke God? What is the theological message in this episode?

To answer the first question, it is not the first time in the OT that God is said to be the cause for someone to sin so as to bring down his judgment. ${ }^{31} \mathrm{At}$ the start of the hardening of Pharaoh's heart episodes in Exod 7-9, Yahweh himself claims that he would harden Pharaoh's heart so as to multiply his signs and wonders in the land of Egypt (Exod 7:3). Interpreters attempt to mitigate this by blaming Pharaoh of hardening his heart first and then Yahweh merely

27 Shimei's accusation of David that he is responsible for the death of Saul's household in 2 Sam 16:7-8 represents such a suspicion.

28 The rain came only after David's act of kindness by giving all the Saulides a proper burial, inspired by Rizpah's desperate and poignant act of guarding the corpses.

29 Three years is according to LXX and $1 \mathrm{Chr} 21: 12$, but MT has seven years here.

30 David's trust in Yahweh's mercy paid off, for apparently the plague only lasted for one day instead of three. MT text says that it was "from the morning till the appointed time" (v.15a: מהבקר ועד־ת מועד), while LXX text specifies that it was "from the morning until dinner time" ( $\alpha \pi \mathrm{o} \pi \rho \omega \imath \theta \varepsilon v \varepsilon \omega \varsigma \omega \rho \alpha \varsigma \alpha \rho \imath \sigma \tau \mathrm{c})$ ). See discussion in Cartledge, 1 \& 2 Samuel, 706. The root for "mercy" (רחם) may allude to Exod 34:6 that declares Yahweh's compassionate attribute.

${ }^{31}$ For a thorough study on this issue, see Robert B. Chisholm Jr., "Does God Deceive?" BSac 155 (1998): 11-28. 
reinforced his resolve. Hence we may explain this passage along this line of thought: that it was David who desired to take the census and God just allowed it. ${ }^{32}$ The ancient writer of 1 Chronicles also felt uncomfortable about Yahweh being the instigator of sin, so in the parallel passage, it is "Satan stood up against Israel, and incited David to count the people of Israel" (1 Chr 21:1). ${ }^{33}$ Regardless of who was the cause, it was David who ordered the census to be taken, even against the advice of Joab and his commanders (2 Sam 24:2-4). And David himself also took responsibility of this "sin" and admitted his own guilt (24:10, 17). But why is taking a census a sin?

Many commentators suggest that it was David's misguided self-reliance and pride that motivated him to take the census to know his military might (24:9) ${ }^{34}$ Hence he sinned by his prideful lack of trust in God. But the fact that even Joab, a reckless and hot-headed person, tried so hard to dissuade David from carrying out this policy (24:3) indicates that there must have been some perceived dangers or taboos associated with census taking.

Park investigates various censuses mentioned in the OT and finds that only one passage associates census with taboo. ${ }^{35}$ Exodus 30:11-16 requires each person counted to offer half a shekel as "ransom" price for his life so that no plague would befall him (Exod 30:12). She further discovers that there was a widespread counting taboo in many cultures and that the origin of this counting taboo was related to God's creative act. ${ }^{36}$ It was believed that numbers were somehow related to divine creation and "were the means by which the gods ordered and regulated the world." ${ }^{37}$ She then finds support from biblical passages that link counting and naming to God's creative power (e.g. Ps 147:4; Isa 40:26; Gen 1:1-2:4) ${ }^{38}$ Hence counting was a prerogative of God, and David by taking the census without the divine consent, transgressed the boundary and impinged on "Yahweh's sovereignty and power." 39

32 Cartledge, $1 \& 2$ Samuel, 699-700.

33 Chisholm, "Does God Deceive?" 22-23, tries to harmonize the two parallel accounts of 2 Sam 24 and $1 \mathrm{Chr} 21$ by claiming that God was angered by Israel's sin and hence he played an active role in allowing Satan, who then tempted David, and that Satan, not God, was the deceiver and instigator. Hence both God and Satan played an active role here.

34 Cartledge, $1 \& 2$ Samuel, 700. For a detailed discussion, see Song-Mi Suzie Park, "Census and Censure: Sacred Threshing Floors and Counting Taboos in 2 Samuel 24," HBT 35 (2013): 22-25.

35 Park, "Census and Censure," 27-28.

36 Park, "Census and Censure," 28-30.

37 Park, "Census and Censure," 30.

38 Park, "Census and Censure," 30-32.

39 Park, "Census and Censure," 32. 
But the question remains as to what sin Israel committed to provoke God's wrath in the first place? ${ }^{40}$ The text offers no specific sin of Israel that causes the divine wrath. However, Park concurs with Mary Douglas' conjecture that Israel's request for a king was the reason for Yahweh's wrath. ${ }^{41}$ Since the main issue in the books of Samuel is kingship, which is prompted by the people's request for a king in 1 Sam 8:4-5, it is quite probable that this was the $\sin ^{42}$ Yahweh first expressed his displeasure of the request by telling Samuel that the people were rejecting him as their king. Then Samuel, in his farewell speech, again told the Israelites that they had done great evil in God's sight by asking for a king (1 Sam 12:17). And Yahweh backed him up by sending thunder and rain on that day, an act that stirred up fear in people's mind, and they admitted their sin (12:19). Though Yahweh did not punish them right away, possibly because of Samuel's intercession (12:23), it is conceivable that God reserved his right to punish and would mete out his judgment later. As in the previous incident (2 Sam 21:1-14), God delayed his punishment until an opportune time to carry out.

Moreover, Park argues that the three forms of punishment that God imposed on David were directed against his kingship: ${ }^{43}$ famine was meant to challenge his ability as king to provide economically for his people; pursuit by enemies to show his inability to protect his country militarily; and plague to question his ability to gain divine favour, since kings are supposed to have a special relationship with their deities. ${ }^{44}$ Thus as Park suggests, by inciting David to transgress the boundary by taking the census, Yahweh reasserts

the boundaries that divide him, the divine ruler, from David, the human king, while simultaneously punishing Israel for their disavowal of God's supremacy in asking for a king. ${ }^{45}$

Even though the plague was severe, and seventy thousand people lost their lives in just one day, the narrator scrupulously indicates that it was Yahweh who

40 This question also baffles Jewish interpreters. For various sins proposed, see Joshua J. Adler, “David's Last Sin: Was It the Census?” JBQ 23 (1995): 93-95.

41 Park, "Census and Censure," 37-38. See also Mary Douglas, "Reading Numbers after Samuel," in Reflection and Refraction: Studies in the Biblical Historiography in Honour of A. Graeme Auld, ed. Robert Rezetko, Timothy H. Lim, and W. Brian Aucker (Leiden: Brill, 2007), 146-49.

42 Some question why the plague did not happen in Saul's time. But that was due to Yahweh's mercy, for at that time, Israel was battling the Philistines and fighting for their survival.

43 Park, "Census and Censure," 33-35.

44 This special relationship is seen in the pronouncement of divine sonship of the king by Yahweh, "I will be a father to him, and he will be a son to me" (2 Sam 7:14). Since the well-being of the people depends on the king's ability to please God and that plague is a form of divine judgment, David's kingship would then be jeopardized.

45 Park, "Census and Censure," 38. 
stopped the destroying angel from striking Jerusalem (2 Sam 24:15-16), and thus reducing the plague from three days to one day. ${ }^{46}$ God then sent Gad to inform David to go up to the threshing floor of Araunah the Jebusite and build an altar for Yahweh there. If the Chronicler's account is correct, then that place marks the site for the future temple (1 Chr 21:28-22:1). Hence the temple serves as a reminder to future generations of God's mercy of halting a great plague, restricting it from reaching its full effect. ${ }^{47}$ The temple also signifies the presence and the sovereignty of God in Israel.

\section{Conclusion on the two narratives}

The major theme of 1 and 2 Samuel is kingship. At issue here is the people's rejection of divine kingship in preference for human kings. It is only apt that the two narratives of the concluding chapters bring to light the dangers and grievances that the sins of human kings could cause. The famine shows that God would not tolerate any treacherous act to the vulnerable. And the plague illustrates that even their best king, David, the one after Yahweh's heart, could commit grave sins which brought forth calamities upon his people. Yet amidst these adversities, God's mercy on them and his faithfulness to his covenant never waver, and the future temple signifies his presence among them, a reminder to them that human kings are only earthly representatives of the divine ruler, Yahweh himself.

\section{E DAVID'S WARRIORS}

\section{$1 \quad 2$ Samuel 21:15-22 and 23:8-39}

The two lists of David's warriors (2 Sam 21:15-22; 23:8-39) make up the second tier of the chiasmus of the concluding chapters. The first list is a shorter list featuring four Israelite heroes who killed the giants (הרפה) of Gath during the Israelite wars with the Philistines. Abishai killed Ishbi-benob (21:15-17); Sibbecai the Hushathite slew Saph at Gob (21:18); Elhanan, son of Jaare-Oregim slew Goliath the Gittite (21:19); and Jonathan, son of David's brother Shimeah, killed the six-fingered giant (21:20-21).

46 Fokkelman, Throne and City, 322-23, 326, explains that v. 15 should be the first day of the plague, "from morning to the time of $m \bar{o}$ 'ed [appointed by God]," and that the climax of the first day of destruction is the "ravaging of Jerusalem" in v. 16. "But this climax is too much for God and he cancels it." Then in v. 18 Gad came to see David "on the same day." LXX also specifies the time in v. 15 "from morning until dinner time" indicating that the plague only lasted for one day.

47 Fokkelman, Throne and City, 327. See also p. 331, his insightful comment, "The beginning of the temple is then - in the form of this predecessor, the altar built by David with its corresponding cult — connected to a crisis between God and his people, in which the Lord wielded the classic catastrophes of famine, the sword, and pestilence." 
In the first account David was nearly killed by the rival giant Ishbi-benob and was saved by his nephew Abishai (2 Sam 21:15-17). And David's warriors were so concerned about his safety that they urged him not to go to the battlefield so as not to "quench the lamp of Israel" (v. 17). ${ }^{48}$ This presents a very different picture of David, who is usually portrayed as an invincible warrior leading Israel to many victories (1 Sam 18:6-7, 13-16, 30; 2 Sam 5:17-25). Even during his flight from Absalom, it was his fame as a mighty warrior that made Absalom adopt Hushai's scheme (2 Sam 17:8-14). But here David is described as weak and weary, needing the aid of his loyal warriors to save his life. This candid portrayal of David shows that he did not achieve his military might alone, but owed much to his courageous and loyal warriors, and proves that he was willing to share his glory with his men. ${ }^{49}$

The third account of Elhanan slaying Goliath the Gittite (21:19) also raises concerns. At issue here is: who killed Goliath? One may recall David's rise to fame by killing Goliath in 1 Sam 17. But here it is Elhanan of Bethlehem. In the parallel account, the Chronicler resolves this problem by claiming that "Elhanan, son of Jair, killed Lahmi, the brother of Goliath" (1 Chr 20:5). While many view this as the Chronicler's attempt to harmonize the two texts, Provan et al. persuasively suggest that the Chronicler's account may reflect the original reading, and that 2 Sam 21:19 may have suffered a textual corruption. ${ }^{50}$ Some suggest that Elhanan's achievement was wrongly transferred to David to glorify the king. But as Cartledge comments, "The great details of 1 Sam 17 and the treasured significance of David's altercation with the giant make this unlikely, however." 51 Hence the traditional view that David killed Goliath, remains most probable.

The second longer list of David's warriors in 2 Sam 23:8-39 consists of four sections: the three most honourable heroes (vv. 8-12); a loyal deed by the three members of the Thirty (vv. 13-17); Abishai and Benaiah (vv. 18-23); a name list of the Thirty (vv. 24-39). This list not only records the valiant deeds of David's commanders, it also illustrates David's relationship with his men.

Some of these men were with David since the day when he was an outcast from Saul's court. ${ }^{52}$ Their admiration and loyalty for David was so great that three of them were willing to risk their lives just to get the water from a

48 The same advice was given to David by his warriors in 2 Sam 18:3, when David offered to go fighting with his men against his son Absalom.

49 Contra Brueggemann's argument that the account is to "assault" the royal ideology and to show the dispensability of David. See Brueggemann, "2 Samuel 21-24," 387.

50 Iain Provan, V. Philips Long, and Tremper Longman III, A Biblical History of Israel (Louisville: Westminster John Knox Press, 2003), 224-25.

51 Cartledge, 1 \& 2 Samuel, 645.

52 David G. Firth, 1 \& 2 Samuel, ApOTC 8 (Downers Grove: Inter-Varsity Press, 2009), 538. 
Bethlehem's well to satisfy their master's desire (vv. 13-17). But David refused to drink it, honouring their valiant and loyal deed by pouring it out to the Lord, saying "The Lord forbid that I should do this. Shall I drink the blood of the men who went at the risk of their lives?" (v. 17). Not only did his reaction aroused further allegiance from his warriors, he also led by example of "not lifting his heart above his brothers" (Deut 17:20).

David's followers trusted him with their lives and never questioned his actions or motive that later led David to abuse his power and take advantage of the loyalty of one of them, Uriah the Hittite. Not only did David take his wife, to cover up his adulterous act, David had him delivering his own death letter to Joab (2 Sam 11:14-15). Uriah's name appears at the end of the list (23:39), a sombre reminder of David's treachery and the subsequent grave consequences that transpired..$^{53}$ As Brueggemann aptly comments,

The presence of Uriah reminds those subscribing to the Jerusalem ideology that there is another Governance that will not be mocked. What may be pleasing in the king's eyes may not be pleasing in the eyes of Yahweh (2 Sam 11:25, 27). ${ }^{54}$

\section{Conclusion on the two warriors' lists}

Unlike other ANE royal annals that all the heroic acts are attributed to the king, ${ }^{55}$ these two lists in 2 Sam 21:15-22 and 23:8-23 give the honour to David's warriors. This demonstrates that David was willing to share the honour with his men and was not afraid to show his own vulnerability. This is in stark contrast to Saul's jealousy of David's success (1 Sam 18:9, 11-15, 25, 28-29, etc.).

David was able to win the heart and trust of his followers, partly due to his personal charm, his respect for his warriors, and his justice (1 Sam 30:21-25). But more importantly, it is Yahweh who inspired those warriors to come and join him from early on (1 Sam 22:1-2). Yahweh not only provided David with human resources, he also granted him and his men victories over their enemies. These lists also confirm Yahweh's providence for his chosen one to accomplish his mission.

53 Another name that may associate with David-Bathsheba episode is "Eliam son of Ahithophel the Gilonite" (v. 34). Eliam may be the father of Bathsheba (2 Sam 11:3). If this is indeed the case, then it explains why Ahithophel chose to help Absalom to rebel against David.

54 Brueggemann, "2 Samuel 21-24," 391.

55 For the ancient texts on the Assyrian and Babylonian kings boasting their military successes, see James B. Pritchard, ed. The Ancient Near East: An Anthology of Texts and Pictures (Princeton: Princeton University Press, 1958), 188-202. 


\section{F DAVID'S SONGS}

\section{$1 \quad 2$ Samuel 22:1-51}

The core of the chiasmus of the concluding chapters consists of two Davidic psalms of uneven lengths. The first one, 2 Sam 22:1-51, is almost identical to Ps 18 , with only slight textual variations. ${ }^{56}$ This psalm echoes the Song of Hannah in 1 Sam 2:1-10, in that both mention Yahweh as refuge and salvation for the meek and celebrate the divine power of bringing down the arrogance. ${ }^{57}$ Hannah's song also anticipates David's psalm by mentioning Yahweh giving strength and enabling his anointed (1 Sam 2:10). ${ }^{58}$ Meanwhile David's psalm fulfils the anticipation by praising Yahweh to be "a tower of salvation for his king, and shows steadfast love to his anointed, to David and his descendants forever" (2 Sam 22:51). ${ }^{59}$

This song is David's reflection on Yahweh's wonderful deeds in his life "after Yahweh had delivered him from the hand of his enemies and from Saul's hand" (v. 1) ${ }^{60}$ This song can be divided into three sections: song of deliverance, celebrating Yahweh's salvation for David (vv. 2-20); Yahweh's reward for the king's innocence and faithfulness, stressing David as a righteous and ideal king (vv. 21-28); and song of victory, declaring Yahweh's granting David victories over his enemies (vv. 29-51). ${ }^{61}$ Brueggemann opines that this song is not to celebrate David's kingship but to indict him, since he could hardly be called "righteous and blameless." ${ }^{62}$ But his view runs against the grain of the text, for it is inconceivable that Yahweh would answer him and help him if he was not righteous (vv. 7, 17-21). His self-claim of innocence (vv. 22-25) and his

56 Cartledge, $1 \& 2$ Samuel, 650, concludes that the variances suggest that this psalm is of great antiquity and that Ps 18 is an updated version of it.

57 Childs, Introduction, 273, listed several similar literary elements between the two poems. For a detailed chart on the similarity of themes and words in these two psalms, see Robert Polzin, 1 Samuel, vol. 2 of Samuel and the Deuteronomist: A Literary Study of the Deuteronomic History (San Francisco: Harper \& Row, 1989), 33-34.

58 Childs opined that Hannah's song “offers an interpretive key for this history which is, above all, to be understood from a theocentric perspective. The focus on God's chosen king, his anointed one, David, appears right at the outset, and reveals the stance from which the whole narrative is being viewed." See Childs, Introduction, 273.

59 Satterthwaite, "David in the Book of Samuel," 43, comments that Hannah's song looks forward to God's power of reversing people's fortunes and David's psalm looks back on God's deeds in his life, while David's Last Words (2 Sam 23:1-7), sets the ideal kingship model for David's descendants.

60 Many scholars speculate the time for this psalm may be early in his reign as Israel's king. See the discussion in Cartledge, $1 \& 2$ Samuel, 650-51.

61 So, Brueggemann, "2 Sam 21-24," 388.

62 Brueggemann, "2 Sam 21-24," 389. 
acknowledgment of the success that the Lord had granted him (vv. 29-46) all paint a celebratory mood.

The background information stated in v. 1 of this song may indicate that this psalm was written early in David's reign, ${ }^{63}$ perhaps even before the Bathsheba-Uriah incident. If that is the case, David could then claim his innocence. But even if it is after David's grievous sin with Bathsheba, God, through Nathan, declared that he "had taken away his $\sin$ " (2 Sam 12:13) after David admitted his guilt, though he still had to pay for the sentence that he imposed on himself (2 Sam 12:5-12). Hence with this divine pronouncement of forgiveness, David could reconcile with Yahweh and claim his restored status before Yahweh. ${ }^{64}$ David's experience then serves as a model for later generations to reconcile with their God. ${ }^{65}$ Hence this song aims to commemorate Yahweh's grace and mercy and his deliverance despite human weaknesses.

The middle section (vv. 21-28) can be read as Israel's royal ideology as set out by Deut 17:14-20. The ideal king in Israel is supposed to be Yahweh's representative on earth. His success as a king depends on his relationship with God, which is measured by his obedience to God's Law. Righteousness, humility, and cleanness from sin and iniquity are the virtuous characters that the king should possess to gain divine favour. The fact that David is being set as a standard, against whom all the later kings in Israel's history are evaluated, means that the depiction of David in 22:21-25 is more ideal than real. ${ }^{66}$

The final section (vv. 29-51) is David's reflection of Yahweh's granting him victories over his enemies both inside and outside Israel (vv. 34-46). He attributed all his military prowess and successes to divine provision, just as he did when he first faced Goliath declaring, "the Lord does not deliver by sword or by spear; for the battle is the Lord's" (1 Sam 17:47). The psalm then ends with words echoing Hannah's song "he will give strength to his king and exalt the horn of his anointed" (1 Sam 2:10b; cf. 2 Sam 22:51). The mentioning of Yahweh's steadfast love (חסד) to David and his descendants forever underscores divine promise to David in 2 Sam 7:8-16 and confirms divine election of David.

\section{$2 \quad 2$ Samuel 23:1-7}

This passage is designated as the "last words of David," though most scholars doubt that these are David's last words, for David's deathbed charge to his

\footnotetext{
63 While David had enemies up to 2 Sam 20, 22:1 specifically mentions that the song is "in the day that the Lord delivered him ... and from the hand of Saul."

64 If we let the superscription of Ps 51 stand, then we could see David's genuine remorseful penitence, begging God to cleanse his sins and to create a clean heart and a renewed spirit.

65 Cartledge, 1 \& 2 Samuel, 658-60, also has a similar idea.

66 So Cartledge, 1 \& 2 Samuel, 675.
} 
successor Solomon is recorded in $1 \mathrm{Kgs} 2: 1-9 .{ }^{67}$ The introductory words "The oracle of David, the son of Jesse, the oracle of the man whom God exalted, the anointed of the God of Jacob, the delight psalmist of Israel" are reminiscent of Balaam's Oracles. ${ }^{68}$ Since Balaam's Oracles are considered to be of great antiquity, ${ }^{69}$ this passage may also be ancient, probably from the time of David. The crux of the message of this oracle is to exhort David and all rulers after him to rule justly and to govern in the fear of God (v. 3). Then the psalmist reflects on God's covenant with David (2 Sam 7), calling it an "everlasting covenant" (ברית עולם).

David's last words reveal his deep desire to be a just king and to rule in the fear of God. He certainly wished that all his descendants who succeeded him would do the same to live out the ideal kingship and to ensure the continuation of the covenant that God had made with him. The contrast between the depictions of the righteous king as a rising sun (v. 4) and the wicked as thorns (vv. 6-7), is to urge the future kings to make the right choice of following the law and to bring divine blessings to himself and to his country rather than curses.

\section{Conclusion on David's Songs}

The songs of David celebrate Yahweh's attributes: his power as manifested in the theophany (2 Sam 22:8-16); his mercy as he delivers those who seek refuge in him (22:2-7, 17, 31-33); his righteousness for he reverses people's fortunes and would not allow the strong to take advantage of the weak (22:18-20, 26-28); and his grace of delighting in David (22:20), a man who had many flaws of his own and yet experienced amazing divine forgiveness.

The songs also commemorate Yahweh's election of David as his anointed one by attributing David's military prowess and victories to Yahweh (22:34-51). David knew that all his success was due to divine favour and that it was Yahweh who set him up as the head of the nations (22:41-44). This divine election underscores Yahweh's covenant with David (2 Sam 7:8-16; cf. 23:5).

In response to the divine election, the requirements for the ideal kingship are spelled out: the king is supposed to be righteous, keep himself clean from sins and iniquities; rule the people justly and in the fear of the Lord by keeping

\footnotetext{
67 Some argue that this might be David's final public words. See Firth, $1 \& 2$ Samuel, 525.

68 See Cartledge, $1 \& 2$ Samuel, 669, for the similarity of the two openings.

69 For a detailed study on Balaam's oracles and the possible date of Balaam, see William F. Albright, "The Oracles of Balaam," JBL 63 (1944): 207-33. Albert M. Wolters, "The Balaamites of Deir 'Alla as Aramean Deportees," HUCA 59 (1988): 10113, suggests that the inscription of Balaam found in Deir "Alla served to preserve the memory of Balaam son of Be'or, the Aramaic diviner from northern Syria.
} 
divine ordinances and statutes $(22: 21-25 ; 23: 3-4)$. David is set as a standard for the ideal kingship, against whom all the future kings in Israel are evaluated.

\section{G THE PURPOSE OF 2 SAMUEL 21-24}

Kingship is the main concern of the books of Samuel. These two books record the evolution of Israel from a tribal league society to a monarchical system. 2 Samuel 21-24 as the concluding chapters of the whole Samuel corpus function as a theological reflection on this issue. Some of the questions that are raised by kingship are: How did God view kingship? What role did God play in the establishment of Israel's kingship? Did God display favouritism in his dealings with the first two kings of Israel, namely, Saul and David? What did ideal kingship in Israel look like?

Both Samuel and Yahweh were greatly offended by Israel's request for a king, viewing it as people's rejection of them. Despite his displeasure with the people, God still told Samuel to accede to their demand but warn them about the grievances that kingship would bring (1 Sam 8:4-9). This shows divine longsuffering and his willingness to accommodate human weaknesses. Subsequently Yahweh chose Saul, a man of great physical stature (1 Sam 9:2), to be their king, according to their wish (1 Sam 10:23-24; 12:13). ${ }^{70}$

Saul's tenure as the first king of Israel turned out to be a complete failure. Some scholars think that Saul's kingship was doomed right from the beginning, for Yahweh never spoke to him directly, and Saul's inquiries went unanswered. ${ }^{71}$ But Saul was empowered by God with a new heart and with divine spirit right after he was anointed by Samuel (1 Sam 10:9-10). Samuel even told Saul what he would encounter and commissioned him to do what his "hand finds to do," presumably to fight the enemies, and assured him of God's presence (1 Sam 10:7). Saul's lack of action after he encountered all the signs and his concealing of the experience from his uncle suggest his "timidity rather than humility.", Later his hiding by the baggage when elected at Mizpah (10:17-22) also shows either his timidity or his reluctance to assume the office, both portray him negatively. ${ }^{73}$

70 It is ironic that Saul may have a stature comparable to a giant, but he is no match for a real giant from Gath, Goliath (1 Sam 17:1-11). Yahweh's comment to Samuel regarding Eliab, "Do not look on his appearance or on the height of his stature...for human look at the outward appearance but the Lord looks at the heart" (1 Sam 16:7) may allude to Saul's physical appearance as one desired by the people.

71 Randall C. Bailey, "The Redemption of YHWH: A Literary Critical Function of the Songs of Hannah and David," BibInt 3 (1995): 225.

72 V. Phillip Long, The Reign and Rejection of King Saul: A Case for Literary and Theological Coherence (Atlanta: Scholars Press, 1989), 211.

73 Long, Reign and Rejection, 218. 
Despite his shortcomings, it was only after he failed the test twice that God decided to reject him (1 Sam 13:8-14; 15:10-30). In the first case, Samuel's delay in arrival is to test Saul's faith in God (1 Sam 13:8-14), ${ }^{74}$ to see if he would trust that divine deliverance does not depend on the number of fighters, just as Jonathan declared to his armour-bearer (1 Sam 14:6). Long argues that Saul's sin was not in committing a cultic crime by offering the sacrifice, but in failing to wait for Samuel's arrival as he was charged to do. ${ }^{75}$ His own words also implicated his fear of people rather than Yahweh's command through Samuel (1 Sam 13:11-12). In the second case, the Amalekite ban is to test his obedience to divine command, to see if he would be enticed by the material gains not to follow God (15:10-30). ${ }^{76}$ Long insightfully comments that Saul's refusal to carry out the ban "connotes disregard of the word of Yahweh and thus, of the theocratic authority structure requisite to acceptable kingship in Israel." 77 Saul fell short on both accounts. ${ }^{78}$ Long further opines that Saul's basic offence in both of these cases is the same: he challenged the authority structure established by Samuel for the co-existence of human kingship and theocracy. And his disobedience "is presented as the moral equivalent of rebellion, which in turn is likened to divination and idolatry."79

Saul's failure was partly due to his personality flaws, his lack of selfconfidence and leadership, as well as his jealousy; but mainly due to his halfhearted faith in Yahweh and his disobedience to divine command. He seemed to be more concern in gaining people's approval than God's (1 Sam 13:8; 15:2431). After Samuel's pronouncement of Yahweh's rejection of him to be king (15:26-29), Saul never accepted Yahweh's decision and still tried to cling on to

74 Many scholars are perplexed by Samuel's accusation of Saul's failure to wait for him since it was Samuel himself who was late (1 Sam 13:8-9). For a detailed discussion on various scholars' views, see David M. Gunn, The Fate of King Saul: An Interpretation of a Biblical Story, JSOTSup 14 (Sheffield: JSOT Press, 1980), 33-40.

75 Long, Reign and Rejection, 87-90.

76 Gunn, Fate of King Saul, 46-56, does not think that Saul had committed a "holy war" crime of for according to Saul's explanation, he took the spoil to sacrifice to Yahweh in Gilgal (1 Sam 15:15), and that Saul and the people might not distinguish the difference between זבח and הuם and the incident of Achan in Josh 7 makes this argument indefensible. Surely the Israelites knew what a ban (חרם) meant since they had done that in their early conquests of Jericho and Ai. Achan's punishment should serve as a reminder of the consequence of disobedience. Gunn also overlooks the motivation of Saul's erection of a monument in Carmel to celebrate his own achievement (v. 12), an act that aimed to glorify himself rather than God. Saul's blaming the people (v. 24) also incriminated himself of listening to the people rather than obeying God's command.

77 Long, Reign and Rejection, 167.

78 Contra Gunn's view, who thinks that Saul has done nothing essentially wrong in both cases. See Gunn, Fate of King Saul, 56.

79 Long, Reign and Rejection, 167. 
his throne by attempting to eliminate David, whom he regarded as a threat to his kingship (18:5-20:42; 23:7-14, 19-29; 29:1-22; 26:1-25) ${ }^{80}$ His jealousy and fear of David led him to massacre the priestly city of Nob (1 Sam 22:11-23), thus setting himself up as an enemy of Yahweh. ${ }^{81}$ Saul's desperate act of seeking an oracle from the witch of Endor before his death was his last act of defiance to Yahweh's law, thus sealing his and his children's fate (1 Sam 28). Hence Saul became a negative example of disobedience, which brought down the covenantal curses upon his country and his household as what Samuel had warned them (1 Sam $12: 15 ; 28: 16-19)$.

Some scholars feel that David's sin with Bathsheba and his subsequent murder of Uriah is just as severe as Saul's, and question Yahweh's leniency on David. ${ }^{82}$ But what differentiates David from Saul is that he always trusted Yahweh whole-heartedly. It was his trust in God that made him such a delight to others. Jonathan was attracted to him right away (1 Sam 18:1-4), so was Michal (18:20) and all the people (18:16). Even when he was exiled from Saul's court, he was able to draw people to follow him (22:1-2). Mark K. George points out that David demonstrated his faith in Yahweh by his frequent inquiries of God, seeking his guidance and counsel consistently and continually, as well as constantly declaring Yahweh's deeds on his behalf. ${ }^{83}$ Contrary to Saul's reaction to divine judgment, after the Bathsheba/Uriah incident, David repented and submitted himself to divine sentence, even to the extent of enduring Shimei's curse (2 Sam 16:11). Hence David's faith in Yahweh and his trust in God became an exemplar for all future generations to emulate.

Even though God had a negative view of kingship, out of his mercy and grace, he allowed Israelites to get their wish, and he was actively involved in the appointment of their kings. The first two kings of Israel served as two examples of human kingship, one totally negative, and the other more positive. In the case of Saul, it was his disobedience of God's command that led to his rejection. $\mathrm{He}$ further set himself up as God's enemy by the massacre of Nob, thus bringing forth divine wrath upon himself and his descendants (Exod 34:7). In David's case, though he had many faults and weaknesses, his trust and submission to

80 Compare to Eli, after he learnt of Yahweh's sentence on his household, Eli submitted himself to God and said, "He is Yahweh, let him do what seems good to him" (1 Sam 3:18).

81 The irony is that Saul failed to obey God's command to carry out a ban on Amalekites, God's enemy, yet he had no trouble in annihilating the city of Yahweh's priests.

82 Bailey, "Redemption of YHWH," 227-29, even questions divine justice on meting out judgment on David's household (children and concubines) rather than David himself. But sometimes what happens to one's loved ones is even more painful and unbearable, David's mourning for Absalom's death illustrates this (2 Sam 18:33).

83 For a discussion on how the narrative makes apparent of David's faith on Yahweh, see Mark K. George, "YHWH's Own Heart," CBQ 64 (2002): 453-57. 
God's authority deemed him worthy to be Yahweh's chosen one (1 Sam 13:14). Yahweh is just in his dealings with the first two kings. The two narratives of famine and plague in 2 Sam 21:1-14 and 24:1-25 reinforce this assessment. They also demonstrate that divine warnings through Samuel did come to pass (1 Sam 8:11-18; 12:14-15): that people did suffer because of their king's sins.

In the famine case, the execution of the seven Saulides was the ransom price demanded by the Gibeonites, Saul's victims. This narrative shows that God is faithful and that he would not let sin against the vulnerable to go unpunished (2 Sam 21:1-2). In the case of the plague, David repented and confessed his sin (2 Sam 24:10), albeit it was God who incited him to take the census in the first place. David further showed his faith by choosing to fall in God's hand (24:14). His trust in divine mercy was not in vain, for God did reduce the plague to one day and accepted his offerings. Hence David became a paradigm for future generations that genuine repentance is the only way to gain divine compassion and forgiveness. ${ }^{84}$ God's halting of the plague also reveals his compassion and mercy amidst judgment (24:16). And the future temple signifies his presence and sovereignty in Israel.

God also provided David with appropriate people to help him build his kingdom. The two lists of warriors show that David did not achieve his military successes by himself. He did it with the help of his loyal and valiant warriors, who risked their lives for his kingdom. And most of all, it was Yahweh who granted him and his men victories over their enemies. Uriah's name appeared at the end of the list of the Thirty, a perpetual reminder of David's sin, and a stern warning to all future kings of the danger of abusing royal power. ${ }^{85}$

The two psalms at the core of the chiasmus of the concluding chapters give a complete picture of Yahweh's involvement in David's life and thus confirm the divine election of David. The use of many metaphors to describe Yahweh in 2 Sam 22:2-4 recalls David's days of hiding from Saul's pursuits (1 Sam 21:1-27:7). Indeed, David's survival depended solely on Yahweh's protection and deliverance. David also attributed all his military prowess and victories to Yahweh (2 Sam 22:34-49), thus indicating that kingship in Israel is to be granted by Yahweh, not to be grabbed by individual. ${ }^{86}$

\footnotetext{
84 The fact that the plague narrative follows the mention of Uriah in 23:39 further enhances this point.

85 So, Firth, 1 \& 2 Samuel, 538-39.

86 David's sparing of Saul's life twice when he had chances to kill him (1 Sam 24:1$22 ; 26: 6-25)$, indicate that he understood this principle and was willing to wait for God's time. Gunn observes that David's success comes when he is most attuned to giving, but his grasping leads to disasters. See his book David M. Gunn, The Story of King David: Genre and Interpretation, JSOTSup 6 (Sheffield: JSOT Press, 1978), 95.
} 
In response to God's granting of kingship, the responsibilities of an ideal king are stated: the king is to be righteous, to keep himself clean from sins and iniquities, to walk in the way of the Lord by keeping his ordinances and laws, in short, to rule in the fear of God (2 Sam 22:21-25; 23:3-4). These guidelines for the future kings are to ensure the continuation of divine covenantal blessings upon his dynasty and his country.

In sum, even though Israel's request for king was against the divine will, God, out of his compassion and grace, let them get their wish by appointing leaders for them and guiding them along the way. 2 Samuel 21-24 as concluding chapters to the Samuel corpus give a succinct theological reflection on Israel's journey from a tribal league to a monarchy and set out a royal ideology for the kingship in Israel. The core of the chiasmus of these chapters emphasizes the divine election of David, and the requirement of kingship in Israel: that the king should rule under the guidance and governance of the One True King, Yahweh.

\section{BIBLIOGRAPHY}

Adler, Joshua J. "David's Last Sin: Was It the Census?” JBQ 23 (1995): 91-95.

Albright, William F. “The Oracles of Balaam." JBL 63 (1944): 207-33. https:// doi.org/10.2307/3262320

Auld, A. Graeme. "A Factored Response to an Enigma." Pages 359-66 in For and Against David: Story and History in the Books of Samuel. Edited by A. Graeme Auld and Erik Eynikel. Leuven: Peeters, 2010.

Bailey, Randall C. "The Redemption of YHWH: A Literary Critical Function of the Songs of Hannah and David." BibInt 3 (1995): 213-31. https://doi.org/10.1163/156851595X00294

Bergen, Robert D. 1, 2 Samuel. NAC. Nashville: Broadman \& Holman, 1996.

Brueggemann, Walter. "2 Samuel 21-24: An Appendix of Deconstruction?" CBQ 50 (1988): 383-97.

Campbell, Antony F. "2 Samuel 21-24: The Enigma Factor." Pages 347-58 in For and Against David: Story and History in the Books of Samuel. Edited by A. Graeme Auld and Erik Eynikel. Leuven: Peeters, 2010.

Carlson, Rolf A. David, the Chosen King: A Traditio-Historical Approach to the Second Book of Samuel. Uppsala: Almqvist \& Wiksell, 1964.

Cartledge, Tony W. 1 \& 2 Samuel. SHBC. Macon: Smyth \& Helwys, 2001.

Childs, Brevard S. Introduction to the Old Testament as Scripture. Philadelphia: Fortress, 1979.

Chisholm, Robert B. Jr. 1 \& 2 Samuel. TTCS. Grand Rapids: Baker, 2013. . "Does God Deceive?" BSac 155 (1998): 11-28.

Douglas, Mary. "Reading Numbers after Samuel." Pages 139-53 in Reflection and Refraction: Studies in Biblical Historiography in Honour of A. Graeme Auld. Edited by Timothy H. Lim, Robert Rezetko, and W. Brian Aucker. Leiden: Brill, 2007.

Exum, J. Cheryl and J. William Whedbee. "Isaac, Samson, and Saul: Reflections on the Comic and Tragic Visions." Semeia 32 (1984): 5-40.

Firth, David G. 1 \& 2 Samuel. ApOTC. Downers Grove: Inter Varsity, 2009. 
. Review of II Samuel 21-24: Context, Structure, and Meaning in the Samuel Conclusion, by Herbert H. Klement. OTE 15 (2002): 831-33.

Fokkelman, Jan P. Throne and City: II Samuel 2-8 and 21-24. Vol. 3 of Narrative Art and Poetry in the Books of Samuel: A Full Interpretation Based on Stylistic and Structural Analysis. Assen: Van Gorcum, 1990.

George, Mark K. "YHWH's Own Heart.” CBQ 64 (2002): 442-59.

Gunn, David M. The Story of King David: Genre and Interpretation. JSOTSup 6.

Sheffield: JSOT Press, 1978.

. The Fate of King Saul: An Interpretation of a Biblical Story. JSOTSup 15. Sheffield: JSOT Press, 1980.

Klement, Herbert H. "Structure, Context and Meaning in the Samuel Conclusion (2 Sa. 21-24)." TynBul 47 (1996): 367-70.

Long, V. Philip. The Reign and Rejection of King Saul: A Case for Literary and Theological Coherence. SBLDS 118. Atlanta: Scholars Press, 1989.

McCarter, P. Kyle Jr. II Samuel: A New Translation with Introduction and Commentary. AB 9. Garden City: Doubleday, 1984.

Park, Song-Mi Suzie. "Census and Censure: Sacred Threshing Floors and Counting Taboos in 2 Samuel 24.” HBT 35 (2013): 21-41. https://doi.org/10.1163/ $\underline{18712207-12341245}$

Polzin, Robert. 1 Samuel. Part 2 of Samuel and the Deuteronomist: A Literary Study of the Deuteronomic History. San Francisco: Harper \& Row, 1989.

Pritchard, James B. The Ancient Near East: An Anthology of Texts and Pictures. Princeton: Princeton University Press, 1958.

Provan, Iain, V. Philips Long, and Tremper Longman III. A Biblical History of Israel. Louisville: Westminster John Knox Press, 2003.

Satterthwaite, Philip E. "David in the Book of Samuel: A Messianic Hope?" Pages 41-65 in The Lord's Anointed: Interpretation of Old Testament Messianic Texts. Edited by Philip E. Satterthwaite, Richard S. Hess, and Gordon J. Wenham. Grand Rapids: Baker, 1995.

Sellars, Dawn Maria. "An Obedient Servant? The Reign of King Saul (1 Samuel 1315) Reassessed.” JSOT 35 (2011): 317-38. https://doi.org/10.1177 /0309089211398710

Sheppard, Gerald. Wisdom as a Hermeneutical Construct: A Study in the Sapientializing of the Old Testament. Berlin: de Gruyter, 1980. https://doi.org/ $\underline{10.1515 / 9783110837087}$

Tushima, Cephas T. A. The Fate of Saul's Progeny in the Reign of David. Cambridge, UK: James Clarke \& Co, 2011.

Wolters, Albert M. “The Balaamites of Deir 'Alla as Aramean Deportees.” HUCA 59 (1988): 101-13.

Grace Ko PhD, Assistant Professor of Biblical Studies / Adjunct Professor of Biblical Studies, Canadian Chinese School of Theology / Tyndale Seminary, 3377 Bayview Ave., Toronto, ON Canada M2M 3S4, Tel: 416-226-6620 Ext 6791, Email: gko@tyndale.ca. ORCID ID: https://orcid.org/0000-0001-9225$\underline{5593}$ 